\title{
The Impacts of Gadget Use on Maqasid Shariah in the Context of Mind Preservation: A study among UiTM Shah Alam Students
}

\author{
Sharifah Fadylawaty Syed Abdullah, Fadhilah Adibah Ismail, Azizah Zakaria, Kamariah Yusoff \\ Academy of Contemporary Islamic Studies (ACIS), \\ Universiti Teknologi MARA (UiTM), Shah Alam, 40450, Selangor, Malaysia \\ fadylawaty4935@uitm.edu.my, fadhilah97@uitm.edu.my, aziza101@uitm.edu.my,kamar143@uitm.edu.my \\ Tel of 1 st Author: $+60119-9320469$
}

\begin{abstract}
This paper focuses on 'The Impacts of Gadget Use on Maqasid Shariah in the Context of Mind Preservation: A study among UiTM Shah Alam Students'. One of the positive impacts of using gadgets is to increase awareness among respondents. Use of gadgets in Islam must, therefore, be subject to the restrictions of Islamic law. It is hoped that this study will help the relevant parties to address the abuse of gadgets by recommending the appropriate guidelines for the optimal, decisive, comprehensive, balanced and practical use of devices among adolescents from the Islamic perspective.
\end{abstract}

Keywords: maqasid Shariah; mind preservation; gadgets; impact, mind function

eISSN: 2398-4287@ 2021. The Authors. Published for AMER ABRA cE-Bs by e-International Publishing House, Ltd., UK. This is an open access article under the CC BYNC-ND license (http://creativecommons.org/licenses/by-nc-nd/4.0/). Peer-review under responsibility of AMER (Association of Malaysian Environment-Behaviour Researchers), ABRA (Association of Behavioural Researchers on Asians/Africans/Arabians) and cE-Bs (Centre for Environment-Behaviour Studies), Faculty of Architecture, Planning \& Surveying, Universiti Teknologi MARA, Malaysia.

DOI: https://doi.org/10.21834/ebpj.v6iSl5.2946

\subsection{Introduction}

Dynamic and rapid technological advances are currently being witnessed by the inventions of sophisticated and modern gadgets as the backbone of contemporary society (Eri Satria Yudatama, Nurhadi, and Atik Chess; 2015; Abdul Kadar Muhammad Masum, 2013; Charles Chukwuemeka \& Okika Agboola Bukola Blessing, 2017). The use of gadgets such as smartphones, tablets, laptops and the like has become a significant global phenomenon in simplifying day-to-day affairs among adults, adolescents and children (Marilyn Campbell, 2005; Syed Naeem Badshah, Hussain Farooq, Hafiz Hifazatullah, Naseeb Dar, Kafait Ullah Hamdani, 2012 \& Charles Chukwuemeka \& Okika Agboola Bukola Blessing, 2017). The borderless world in the era of globalization has made people, regardless of age, highly dependent on the use of gadgets. They have been exposed to devices as early as infants and children, adolescents, youth, adults and the elderly (Syed Naeem Badshah, Hussain Farooq, Hafiz Hifazatullah, Naseeb Dar, Kafait Ullah Hamdani, 2012).

Various applications can now be accessed via mobile phones, computers, laptops and smartphones. Fundamentally, there are many positive effects of using a gadget. Still, abuse can lead to harm and pose a significant threat to society, especially to adolescents (Abdul Kadar Muhammad Masum, 2013).Islam, as a civilized religion, does not discard technology, but its use must be harmonized with Islamic principles. It is, therefore, essential to assess whether the use of gadgets is beneficial or harmful to humans. In this regard, this paper will discuss 'The Impact of Gadget Use on Maqasid Shariah in the Context of Mind Preservation: A Study Among UiTM Shah Alam Students.'

eISSN: 2398-4287C 2021. The Authors. Published for AMER ABRA cE-Bs by e-International Publishing House, Ltd., UK. This is an open access article under the CC BYNC-ND license (http://creativecommons.org/licenses/by-nc-nd/4.0/). Peer-review under responsibility of AMER (Association of Malaysian Environment-Behaviour Researchers), ABRA (Association of Behavioural Researchers on Asians/Africans/Arabians) and cE-Bs (Centre for Environment-Behaviour Studies), Faculty of Architecture, Planning \& Surveying, Universiti Teknologi MARA, Malaysia. 


\subsection{Literature Review}

Intellectual preservation is a crucial point to be emphasized in Islam, as it is one of the five essential elements of Maqasid Shariah namely the preservation of religion, life, intellect, lineage and wealth. The mind needs to be holistic and balanced. Every effort that can nourish the function of human intelligence should always be encouraged. While, things that may impair the function of the mind, such as the use of alcohol is prohibited. The use of gadgets in Islam is subject to the Islamic law. Its use is prohibited if it leads to a negative impact which may affect human cognitive functions such as dependence and addiction.

Humans are unique in comparison to other creatures as they are endowed with mental powers which leads them to make rational choices and considerations for their actions. The word intellect is derived from the phrase 'aqala-ya'qilu, meaning mind, rationality, and intelligence. The opposite meaning of intellect is ignorance (Joseph Dalhat, 2015). In short, intellect refers to the intellectual capacity to receive, understand and synthesize information to evaluate between right and wrong based on the acquisition of knowledge by divine sources (Yusuf Dalhat, 2015; Mamatha SL, Pooja A Hanakeri \& Vijayalaxmi A Aminabhavi, 2016).

In Islam, the mind plays a vital role in realization the message of the Prophet Muhammad PBUH) to glorify the Almighty for the attainment of blessing, and happiness in the world and hereafter (Yusuf Dalhat, 2015). Humans who act based on religious guidelines recognized as wise individuals from an Islamic point of view (Yusuf Dalhat, 2015). On the other hand, those who use the logic of reason alone without reference to the guidance of revelation are condemned by Islam because human intellect is minimal. Therefore, it is the responsibility of the human being to use this precious gift to recognize and reflect on the signs of God greatness to strengthen trust and faith in Him.

The word 'Maqasid' literally means purpose, objective, principle and intention (Muhammad Adil Khan Afridi, 2016). Whereas the Maqasid Shariah stands for the purpose behind the Islamic rulings. In general, each rule is designed to provide good (maslahah) and avoid evil (mafsadah) for the sake of worldly and ukhrawi (Nasrul Hisyam Nor Muhamad, Mohd Arafat Jaafar, Muhibbuddin Abdullah, Nurul Atikah Nizaludin, Mohd Muslim Salleh \& Mohd Muammar Mohd Zin, 2015; Azman Ab Rahman, Syed Mohd Najib Syed Omar \& Siti Zulaikha Mokhtar, 2017).

There are three (3) level of Maqasid Shariah, namely al-dharuriyyat (necessity), al-hajiyyat (desire) and al-tahsiniyyat (perfection) (Norazmi Anas, Ahmad Fadhir Mat Dahan \& Zuriani Yaacob, 2016; Azman Ab Rahman et al., 2017).Dharuriyyat aims to take care of basic needs for the survival and well-being of human life, such as home, health and clothing. Without Dharuriyyat, human life is affected and chaotic (Azman Ab Rahman et al., 2017). Dhaririyyat emphasizes the five main components comprising of religion (al-din), life (alnafs), intellect (al-aql), lineage (al-nasl) and wealth (al-mal) for the continuation of human life (Siti Aishah Maliki, Rahimah Embong \& Berhanundin Abdullah, 2015). Hajjiyyat functions to minimize life's difficulties, such as the rukhsah of prayer while travelling. The third category, Tahsiniyyat, refers to things that lead to the comfort and perfection of life (Siti Aishah Maliki et al., 2015).

Significantly, individual development, especially adolescents, needs to be holistically developed, covering emotional, moral, cognitive and social issues (Siti Aishah Maliki et al., 2015). The Maqasid Shariah approach is seen as relevant because it focuses on actions that need to be taken to preserve the mind in different circumstances (Azman Ab Rahman et al., 2017).

\subsection{Methodology}

The study uses quantitative methods, and the instrument used is a questionnaire survey. The respondents were students of different faculties at Universiti Teknologi MARA (UiTM) Shah Alam. Random Sampling Technique was the sample selection used. Descriptive data analysis is performed via Google Docs to generate research findings.

\subsection{Findings}

A study entitled 'The Impacts of Gadget Use on Maqasid Shariah in the Context of Mind Preservation: A Study Among UiTM Shah Alam Students' was conducted involving 370 respondents from different faculties.

\subsection{Demographic Respondents}

$63.7 \%$ of the respondents were female, while $36.3 \%$ were male. The majority of the respondents between 18 and 23 years of age (97.6 per cent) and 87.7 per cent were undergraduates, while the rest were postgraduates. Most of them were studying at UiTM Shah Alam in full-time mode (99.5 per cent). More than $50 \%$ of the respondents were from the Academy of Contemporary Islamic Studies (ACIS). While the rest were from different faculties such as the Faculty of Engineering (Electrical, Mechanical, Chemical and Civil), the Faculty of Applied Sciences, the Faculty of Computer and Mathematical Sciences, the Faculty of Communication and Media Studies, the Faculty of Art and Design, the Faculty of Architecture and Design and others.

\subsection{Use the gadgets}

Smartphones were the most dominant type of gadget for respondents $(99.2 \%)$, followed by laptops (88.6\%) and tablets $(5.4 \%)$. The study found that there are various amount allocated to the use of gadgets from RM10 to more than RM50 per month. Most of the respondents spent more than 4 hours a day on the gadget.

Specifically, only 8.7 per cent allocated between 1-3 hours to the gadget, while 35.3 per cent used the gadget between 4- 6 hours a day, 33.2 per cent spent about $9-12$ hours a day, and 9 per cent spent more than 13 hours a day on the gadget. 97.8 per cent of respondents reported using gadgets to browse social media sites such as Instagram, Facebook, Twitter, and Whatsapp. Access to educational 
websites was also high, accounting for $52.2 \%$ of respondents, followed by entertainment, sports and politics. However, there is less access to science-based sites, current issues, religion, economics, medicine, and others.

\subsection{The Impacts of Gadgets Use}

The main aspects studied in the survey were the positive and negative impacts of gadgets use from the perspective of the respondents. The results are shown in the following Table 1:

$\begin{array}{llc}\text { No } & \text { Impacts of Gadgets } & \begin{array}{c}\text { Table 1: The Positive Impacts of Gadgets Use } \\ \text { Strongly disagree } \\ \text { agree }\end{array} \\ 1 & \text { Gadgets help me to explore and improve my knowledge. } & 1 \\ 2 & \text { Gadgets help me develop my talents, my potentials and my creativity. } & 0.3 \% \\ 3 & \text { Gadget exposes me to a whole new range of information. } & 0 \% \\ 4 & \text { Gadgets keep me up to date with the latest issues. } & 0 \% \\ 5 & \text { Gadgets are helping me relieve stress. } & 1.1 \% \\ 6 & \text { Gadgets are helping to boost my confidence. } & 1.4 \% \\ 7 & \text { Gadgets are making my life happier. } & 2.4 \% \\ & \text { Gadgets make me physically and mentally healthier by practising a gadget- } & 4.3 \%\end{array}$

\begin{tabular}{cccc} 
& & \multicolumn{2}{c}{ Strongly } \\
2 & 3 & 4 & 5 \\
$0 \%$ & $7.6 \&$ & $45.5 \%$ & $46.9 \%$ \\
$2.7 \%$ & $23.3 \%$ & $46.6 \%$ & $27.1 \%$ \\
$0.8 \%$ & $9.8 \%$ & $49.9 \%$ & $39.6 \%$ \\
$0 \%$ & $10.6 \%$ & $46.3 \%$ & $43.1 \%$ \\
$3.3 \%$ & $25.9 \%$ & $44.1 \%$ & $25.6 \%$ \\
$8.1 \%$ & $33.3 \%$ & $40.7 \%$ & $16.5 \%$ \\
$5.7 \%$ & $39.1 \%$ & $38.6 \%$ & $14.1 \%$ \\
$12.2 \%$ & $45 \%$ & $26.6 \%$ & $11.9 \%$
\end{tabular}

Source: Field survey (2019)

Fundamentally, there are many positive effects of using the gadget. Still, the abuse of the gadget can lead to harm and pose a significant threat to society, especially to adolescents, as presented in Table 2:

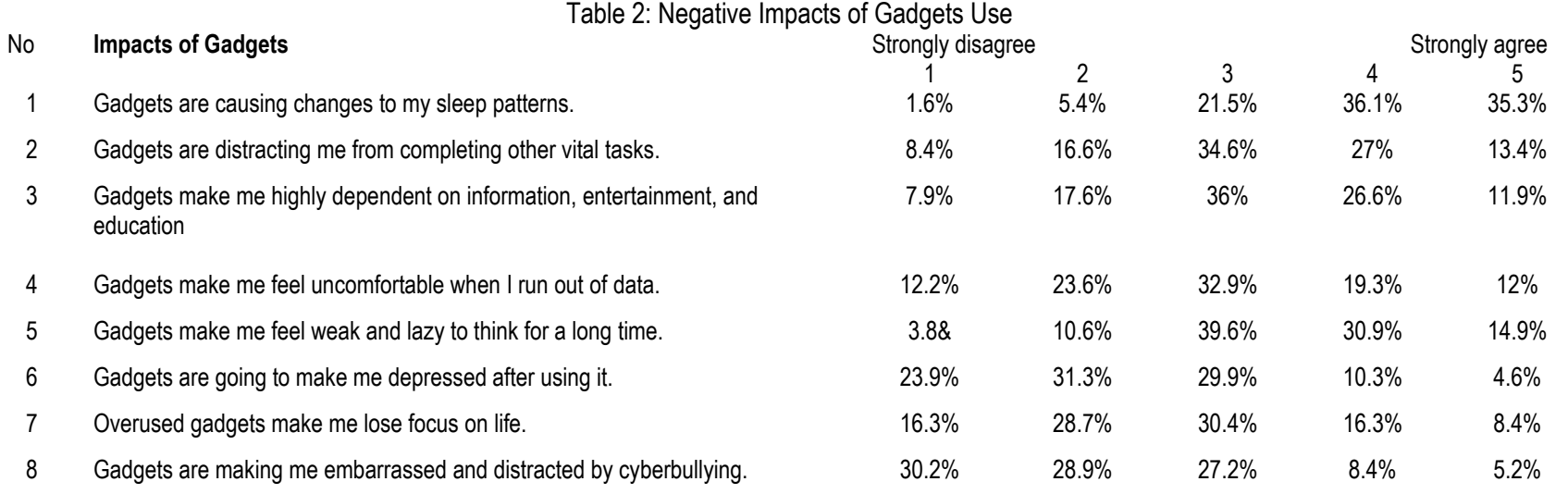

Source: Field survey (2019)

\subsection{Discussions}

The findings show that the use of gadgets has a positive impact on the ability and potential of the respondents. In short, it has been demonstrated that gadgets manage to preserve the minds of the respondents. According to Mahadzirah Mohamad, Nor Azman Mat Ali, Harmy Mohamed Yusoff, \& Nizaita Omar (2015), mindfulness refers to processes of maturity, learning, and education that stimulate the intellectual, emotional, and intuitive powers of the individual. The positive elements that respondents have access to, such as scientific and educational websites, help to nurture their intellect. The findings of the current study are consistent with the views expressed by Muhammad Adil Khan Afridi (2016) that the mind needs to be nurtured with positive things and avoid harmful elements that can ruin the capacity of the mind.

As a result, Islam obliges its followers to seek knowledge. The emphasis on learning in Islam can be seen in the first verse of the Prophet Pbuh (Iqra). The verse points out to Muslims that expertise is vital to liberating humanity from the shackles of ignorance and backwardness. Therefore, the tendency of respondents to use gadgets to access informative websites and applications is strongly encouraged by Islam.

Intellectual potential can also be cherished by inspiring people to think, contemplate and express their views continually. The findings of the current study seemed to support a culture of thinking in which most respondents believed that the use of gadgets was constructive in fostering their talent, potential and creativity. The rational habit of thinking will lead to ijtihad. The implementation of ijtihad is crucial to resolve various contemporary issues that call for a sensible ijtihad or solution by competent mujtahid (Muhammad 
Adil Khan Afridi, 2016). The Prophet Muhammad (PBUH) explained in his hadith that Allah Almighty would reward the mujtahid despite his false decision as an urge for Muslims to think and do something.

Current findings are parallel to previous studies conducted by Mamatha SL, Pooja A Hanakeri \& Dr Vijayalaxmi A Aminabhavi (2016) where they indicated that the use of gadgets was found to enhance the ability to think and reasoning. Computer games designed with a variety of features, for example, can balance cognitive, psychomotor and emotional components of the users (Kaveri Subrahmanyam et al., 2001). Individuals who play video games, for example, have a better ability to process information and visuals (Charles Chukwuemeka \& Okika Agboola Bukola Blessing, 2017). These skills can be developed and applied in their everyday lives.

Respondents have shown that gadgets can provide them with many other positive effects, such as stress relief, boosting selfconfidence, and making their lives happier. At the same time, gadgets make respondents enjoy a healthier life, by practicing a positive lifestyle-derived by device imitation. This result validates the findings of the studies conducted by Mahadzirah Mohamad, Nor Azman Mat Ali, Harmy Mohamed Yusoff and Nizaita Omar (2015). They point out that the preservation of the intellect can be achieved through the character and attitude of the individual. Positive attitudes and charisms have been shown to maintain the potential of the mind through the excellent judgment of actions taken, vigilance in decision-making, continuous effort and optimism in dealing with life trials (Mahadzirah Mohamad et al., 2015).

The benefits of gadgets within the scope of this knowledge have been shown to provide greater unlimited exposure to new ideas, expertise, enhanced knowledge and skills through virtual platforms, as presented in Table 1 above. This finding is consistent with the views of Johari Hassan \& Shahrina King Abdul Rashid (2012), Marziana Abdul Majid (2013), Reid Chassiakos Y, Radesky J, Christakis D, et al. (2016) and Swe Swe Latt \& Maulana Akbar Shah @ U TunAung (2017 ).

While, the excessive use of gadgets has negative implications that can be distracted from one's focus on work and daily tasks (Mamatha SL et al., 2016). This finding is consistent with previous research by Rahayu \& Sun Sun Lim (2015) Mamatha SL et al., 2016). High dependence on gadgets also results in a lack of focus, creativity and problem-solving skills among users (Rahayu \& Sun Sun Lim, 2015). The use of gadgets can lead to nomadic anxiety (exceptionally addictive gadgets), especially among school-aged adolescents (Johari Hassan \& Raja Shahrina Raja Abdul Rashid, 2012). Symptoms of this nomophobia cause users to spend most of their time on the phone, checking a message or visiting social sites regularly. A Norton Online Living Report (NOLR) study in Malaysia conducted by Saffron Hill on behalf of Symantec found that adolescents spend about 16 hours a week surfing the internet (Johari Hassan \& Raja Shahrina Raja Abdul Rashid, 2012). This situation is seen as dangerous and requires reasonable control. The current study found that respondents tended to rely heavily on gadgets for accessing to information, entertainment, and education. More concerned, respondents said they felt uneasy when they ran out of data because it was difficult for them to access gadgets.

Other risks associated with the use of gadgets include adverse effects on emotional instability and fatigue (Rahayu \& Sun Sun Lim, 2015; Reid Chassiakos Y, Radesky J, Christakis D, et al., 2016). The respondents agreed that gadgets would affect the quality of sleep and cause changes in their sleep patterns as they would be disrupted by the gadget message. However, the results of the study show that, on the other hand, the use of gadgets did not significantly cause depression, embarrassed and distracted by cyberbullying to respondents as reported in previous studies.

\subsection{Conclusion and Recommendations}

\subsection{Guidelines for Shariah Compliance Use of Gadget}

Islam does not reject technology, but it must be applied in accordance with the Islamic principles and within the framework of the Maqasid Shariah. Therefore, in the context of the use of gadgets, it is essential to assess whether it is beneficial or harmful to the mind. Anything that may have an impact on intellectual capacity should be avoided.

This paper recommends guidelines for Shariah-compliant use of gadgets for the preservation of the mind from the perspective of Maqasid Shariah. The use of devices that are not guided by the Syariah is feared to have many harmful effects to users (Abdul Kadar Muhammad Masum, 2013). Several aspects have been studied and refined to develop the guidelines for the prudent use of gadgets so that the cyber environment is harmonious and in line with Islamic ethic and Islamic law (Abdul Kadar Muhammad Masum, 2013). The proposed guidelines are comprehensive and can be widely adopted, consist of the following aspects:

\subsection{Limit access time for the use of gadgets}

Limiting the access time to use the device is essential to control the nomophobia symptoms. The duration of time allocation is also significant to determine the impacts of gadget use. Time rates between one and two hours per day as recommended by Rahayu \& Sun Sun Lim (2015) and Charles Chukwuemeka \& Okika Agboola Bukola Blessing (2017) are considered reasonable, especially for children. At the same time, adult monitoring is essential. One of the best ways to do that is to use an inaccessible password.

\subsection{Expand the use of gadgets for positive and non-abusive purposes}

In Islam, every human behaviour will be held liable for good or otherwise. Gadgets are tool or instrument to be used, but not a goal (Abdul Kadar Muhammad Masum, 2013). Islam does not reject the use of technology but must comply with Islamic principles and beneficial to religion and Muslims.

The constraints of time and money today have led to more and more people to apply virtual learning through the web, Youtube, Facebook, and the like. Technology should, therefore, be well used by young people for the right purpose (Amini Amir Abdullah, 2012). For example, gadgets can be used as a knowledge and information platform to groom knowledgeable Muslims (Amini Amir Abdullah, 
2012; Swe Swe Latt \& Maulana Akbar Shah, 2015). Gadgets can also be used to enhance personality, social networking, and so on (Amini Amir Abdullah, 2012).

\subsection{Do not browse websites or pages containing harmful elements}

Users and guardians (parents) are responsible for ensuring that the content of applications and websites does not contain toxic components that are contrary to religion. For examples violent, immoral, violation of community norms, pornography or otherwise should be avoided. Exposure to such harmful sites may encourage users to engage in various forms of abuse, such as e-harassment by sharing pornographic information with their friends (Swe Swe Latt \& Maulana Akbar Shah @ U TunAung, 2017).

Parents need to continuously monitor and apply the concept of sin and reward to their children so that they are always aware that every lousy practice will be punished by Allah the Almighty (Rahayu \& Sun Sun Lim, 2015). Besides, users of gadgets, especially adults, need to have their spiritual filtering tools of faith and piety to prevent them from browsing inappropriate websites (Mohamad Fauzan Nordin, 2013).

\subsection{Not neglecting religious responsibilities}

The use of gadgets for a long time to access online games, can lead to frustration and can cause an individual to neglect his or her religious duties, such as prayer. The user should, therefore, be prudent in setting the gadget usage schedule so that it can be integrated with various other useful activities, such as reciting the Quran, reviewing lessons, and so on. For example, the Maghrib prayer time between 7-8 p.m. is a prohibited time to use gadgets when there is no urgent need to do so (Rahayu \& Sun Sun Lim, 2015).

\section{Acknowledgements}

The authors highly appreciate the funding and support from the Institute of Research Management \& Innovation (IRMI) of University Teknologi MARA (UiTM). This research is funded by the 600-IRMI/Dana KCM 5/3/LESTARI (125/2017) Kesan Penggunaan Gajet

\section{References}

Ab Rahman, A., Omar, S. M. N. S., \& Mokhtar, S. Z. (2017). Analisis Skim Agihan Zakat kepada Asnaf Fi Sabilillah Mengikut Maqasid Syariah: Kajian di Selangor dan Negeri Sembilan. Jurnal Sains Insani, 2(1), 1-6.

Afridi, M. A. K. (2016). Maqasid al-Shari'ah and Preservation of Basic Rights: Under the Theme" Islam and its Perspectives on Global \& Local Contemporary Challenges. Journal of Education and Social Sciences, 4(1).

Anas, N., Dahan, A. F. M., \& Yaacob, Z. (2016). Basic Principles of Shariah: UiTM Law Foundation Student's Attitude \& Perceptions. Jurnal Intelek, 10(2).

Amini Amir Abdullah. (2012). "Etika Digital dan Berinternet Menurut Perspektif Islam". Jurnal Penyelidikan Islam.Bil 25/2012.

Dalhat, Y. (2015). The Concept of al-Aql (Reason) in Islam. International Journal of Humanities and Social Science, 5(9), 1.

Hassan, J., Rashid, R. S. R. A., \& Shahrina, R. (2012). Ketagihan Penggunaan Internet di Kalangan Remaja Sekolah Tingkatan 4 di bandaraya Johor Bahru. Journal of Technical, Vocational \& Engineering Education, 6, 23-43.

Latta, S. S., Shah, M. A., \& TunAungb, U. Internet Usage from Islamic Perspective: A Preliminary Survey with First Year Medical Students, Kuantan Campus, Pahang 2015. International Journal on Recent and Innovation Trends in Computing and Communication, 5(2), 207-213.

Lim, S. S. (2016). Balancing Religion, Technology and Parenthood: Indonesian Muslim Mothers' Supervision of Children's Internet Use. In Mobile Communication and the Family (pp. 33-50). Springer, Dordrecht.

Mamatha, S. L., Hanakeri, P. A., \& Aminabhavi, V. A. (2016). Impact of Gadgets on Emotional Maturity, Reasoning Ability of College Students. Int J Applied Res, 2(3), $749-55$.

Maliki, S. A., Embong, R., Abdullah, B., Sultan, U., \& Abidin, Z. (2015). The Ethical Values Based On Maqasid Syariah For Enhancing Self Identity Among Students. In Proceedings of ICIC2015-International Conference on Empowering Islamic Civilation in the (Vol. 21, p. 287â).

Marilyn Campbell. (2005). "The Impact of the Mobile Phone on Young People's Social Life". Asian Journal of Management Sciences and Education. Social Change in the 21st Century Conference, 28 October 2005, QUT Carseldine, Brisbane.

Marziana Abdul Majid. (2013). "Membudayakan Adab Dalam Penggunaan Internet Dalam Kalangan Pelajar". Proceeding in International Conference on Social Science Research, ICSSR 2013. 4-5 June 2013, Penang, Malaysia. e-ISBN 978-967-11768-1-8. Organized by WorldConferences.net.

Masum, A. K. M. (2013). Ethical Issues in Computer use: A Study from Islamic Perspective. Global Journal of Computer Science and Technology.

Mohamad, M., Ali, N. A. M., Yusoff, H. M., \& Omar, N. (2015). Validating the Measurement of Maqasid Syariah Quality of Life (I-QoL) Model Among Spiritual Rehabilitation Drug Abusers. The International Institute of Advanced Islamic Studies (IAIS), Malaysia.

Muhamad, N. H. N., Jaafar, M. A., Abdullah, M., Nizaludin, N. A., Salleh, M. M., \& Zin, M. M. M. (2015). Konsep Maqasid Syariah Dalam Pengurusan Wakaf (Maqasid Shariah In Waqf Management). UMRAN-International Journal of Islamic and Civilizational Studies, 2(3). 
Noordin, M. F., Othman, R., \& Zakaria, N. A. (2013). Investigating Key Success Factors in Adopting Knowledge Management System. World Applied Sciences Journal, 21(2), 221-229.

Okika, C. C., \& Blessing, A. B. (2017). Escapism by Digital Media: Assessing Screen Time Impact, Usage Guidelines/Recommendations Awareness and Adoption Among Undergraduate Students in Enugu State, South-East Nigeria. International Journal of Advanced Multidisciplinary Research Reports, 2(1).

Subrahmanyam, K., Greenfield, P., Kraut, R., \& Gross, E. (2001). The Impact of Computer Use on Children's and Adolescents' Development. Journal of Applied Developmental Psychology, 22(1), 7-30.

Syed Naeem Badshah, Hussain Farooq, Hafiz Hifazatullah, Naseeb Dar \& Kafait ullah Hamdani. (2012). "Use of Electronic Media for Preaching of Religion in the Light of Sharia." Leena and Luna International, Oyama, Japan.

Yudatama, E. (2017). Smartphone dan Keluarga (Deteritorialisasi Keluarga Pemakai Smartphone di Kota Surakarta). SOSIALITAS; Jurnal IImiah Pend. Sos Ant, 5(2). 